UDC 81'246

DOI 10.18485/primling.2015.16.15

\author{
Barbara Perić \\ Nikolina Božinović \\ RIT Croatia
}

\title{
CROSS-LINGUISTIC INFLUENCES IN SPANISH L3 ACQUISITION BY LEARNERS WITH CROATIAN L1 AND ENGLISH L2
}

\begin{abstract}
Summary: This study addresses the role of previously acquired languages in the acquisition of a third language (TLA). It is focused on cross-linguistic influences (CLI) in Spanish third language (L3) acquisition by learners with Croatian first language (L1) and English second language (L2). As De Angelis (2007) states, transfer has been found to occur from more than one language at the same time. This type of transfer which is referred to as combined $C L I$, remains little explored to date. Through error analysis this study provides evidence that the production of CLI is a tangible representation of the simultaneous activation of all the languages present in the individual's Language Mode (Grosjean, 2001) and also provides evidence to confirm that the type of transfer episodes observed may be related to formal similarity between specific features or components of languages.
\end{abstract}

Key words: Third language acquisition (TLA), Crosslinguistic influences (CLI), Language mode, Transfer, Error analysis, Formal similarity

\section{INTRODUCTION}

Third language acquisition is a relatively new area of research that has expanded rapidly in recent years. Many researchers have taken the position that third language (L3) acquisition (TLA) is simply another case of adult second language (L2) acquisition (SLA) and differences between SLA and TLA have been neglected in SLA research and in studies on bilingualism. Recent research has made clear that interlanguage development of an L2 is not necessarily identical to that of an L3, especially regard to potential sources of transfer (Cenoz et al., 2001; Cenoz, 2003; Leung, 2005; Rothman and Cabrelli Amaro, 2010).

Crosslinguistic influence (CLI), although defined as a field of study concerned with native and non-native language influence, has traditionally focused on L1 influence and L2 learner behaviour. According to De Angelis (2007) a comprehensive theory of CLI cannot, however, be based on L1 influence alone, as a wide range of phenomena would inevitably remain unexplored and unexplained. Multilinguals have knowledge of more than two languages by definition, so the possible sources of influence automatically 
increase with the number of languages the individual is familiar with. As De Angelis (2007) states, transfer has also been found to occur from more than one language at the same time. This type of transfer which is referred to as combined CLI, remains little explored to date. This study is focused on cross-linguistic influences in Spanish L3 acquisition by learners with Croatian L1 and English L2. The purpose of the study is not only to examine Croatian and English CLI, but also to give an overview of combined CLI mentioned above.

\section{THEORETICAL BACKGROUND}

Third language acquisition (TLA) is a field of study that is concerned with learners who have previously acquired two languages and who are in the process of acquiring a new one. Our study is situated within the field of TLA and thus looks at learners who have acquired a second language (L2) - English in the past and are presently in the process of acquiring a third language (L3) - Spanish.

According to De Angelis (2007) the study of crosslinguistic influence seeks to explain how and under what conditions prior linguistic knowledge influences the production, comprehension and development of a target language. The term "crosslinguistic influences" was initially proposed by Sharwood Smith and Kellerman for the phenomena concerning "the interplay between earlier and later acquired languages" (Sharwood Smith and Kellerman, 1986: 1, as reported in Bayona, 2009). As Bayona (2009) states, prior to the pubblication of Sharwood Smith and Kellerman CLI had traditionally been studied following the methodology of error analysis (EA) (Lado, 1957; Corder, 1967). Our study opts for employing Bouvy's classification of the type of errors (Bouvy, 2000) but including some necessary modifications required for the examination of our corpus in particular.

As already mentioned, recent research has made clear that interlanguage development of an L2 is not necessarily identical to that of an L3, especially regard to potential sources of transfer (Cenoz et al., 2001; Cenoz, 2003; Leung, 2005; Rothman and Cabrelli Amaro, 2010). Does transfer in L3 acquisition come exclusively from the L1 as in L2 acquisition (Leung, 2005)? Does it come exclusively from the L2 (Bardel and Falk, 2007; Rothman and Cabrelli Amaro, 2010)? Does it come from both languages (Flynn et al., 2004)?

De Angelis (2007) states that relatedness and formal similarities are important triggers of CLI. Relatedness is defined on the basis of genetic affiliation, whereby languages are said to be related or close to one another when they belong to the same family (e.g. Indo-European) or the same subgroup of a family (e.g. Romance or Germanic subgroups within the Indo-European family). Formal similarity instead explicitly identifies the similarity between specific features or components of languages, ranging from their grammatical structures to their lexicons, phonetic features, graphic forms and so forth. Two unrelated languages can consequently be formally similar with respect to some features or components. We adress these issues in the current study.

Our study also incorporates the interpretation of the mental representation of the language mode of trilinguals as proposed by Grosjean (2001) applied to third language learners. Grosjean proposes the existence of a Language Mode Continuum that consists of a state of (linguistic) activation that ranges from no activation to total activation (Gro- 
sjean, 2001). In other words, the individual may flow from a monolingual state of activation to a bilingual state of activation according to the degree of activation needed. In a later version of his proposal (Grosjean, 2004), he argues that the state of language acquisition is determined by external factors like the listeners, the context or the topic. As for the CLI that are the focus of our study, Grosjean claims that the mere awareness of the possibility of language mixing moves the individual closer to the bilingual or trilingual mode than to the monolingual. As Bayona (2009) states, to this observation it can be added that even if the individual is not aware of such possibility, the presence of a CLI shows that either there has been either an untriggered shift of the mode into a bilingual or trilingual state, acting as a relief strategy for the speaker, or that all the languages in the individual's linguistic repertoire are in a concurrent state of activation in the language mode.

In the case of our participants we hypothesize that they were in a trilingual mode at the time of writing the composition. We were able to identify this state given the explicite presence of lexical elements that may be traceable to three different languages, which indeed constitute CLI evidence. According to this we suggest that a concurrent trilingual mode may in fact be the case in trilingual individuals. As our participants were not aware that their writing would be evaluated for research purposes, we offer an extended perspective for the application of the model in which the activation of previously acquired languages is independent of external factors as originally proposed by Grosjean.

\section{AIM}

This study addresses the role of previously acquired languages in the acquisition of a third language (L3). It is focused on cross-linguistic influences in Spanish L3 acquisition by learners with Croatian L1 and English L2. The purpose of the study is not only to examine Croatian and English CLI, but also to give an overview of combined CLI mentioned above. We pose the following research questions:

a) Does transfer in Spanish L3 acquisition come exclusively from the Croatian L1? Does it come exclusively from the English L2? Does it come from both languages?

b) What role does formal similarity play in this selection process?

Our hypotheses are focused on two major points:

- That the production of CLI is a tangible representation of the simultaneous activation of all the languages present in the individual's Language Mode (Grosjean, 2001)

- $\quad$ That the type of transfer episodes observed may be related to formal similarity between specific features or components of language

As De Angelis (2007) states, finding evidence in favour of language closeness is relatively easy whenever speakers are familiar with a combination of related and unrelated languages and only two of these (the source and the target) are related to one another. 
The question becomes more complex whenever learners are familiar with languages that belong to the same language family, but not to the same subgroup within the family as it is the case with our combination of languages. Croatian, English and Spanish language belong to the same language family (Indo-European languages), but not to the same subgroup within the family. Croatian is a Slavic language, English is a Germanic language and Spanish is a Romance language. With this language background, it is very hard to predict which of the languages already in the mind is most likely to become the learner's preferred source of information during the acquisition process as it is also hard to differentiate the distances of English and Croatian to Spanish if the languages are to be compared as whole sets. Rather, there is a profile of closeness and distance that varies between different areas of the languages (Williams and Hammarberg, 2009).

There are various areas of similarity and dissimilarity between these three languages: Croatian, English and Spanish. Due to the fact that a significant portion of the English vocabulary comes from Romance and Latinate sources and that Spanish and English share many cognate words we can conclude that there are more lexical similarities between Spanish and English than between Croatian and Spanish. According to this, we argue that in the area of lexicon, English language will be the preferred source of language transfer. Basic syntax is typologically similar to a great extent in these three languages so we don't expect to find major errors in syntax. Croatian and Spanish are more similar in the area of morphology due to the fact that Croatian and Spanish have a higher degree of inflection than English. The Romance languages have more overt inflection than English, especially in verb conjugation. Adjectives, nouns and articles are less inflected than verbs, but they still have different forms according to number and grammatical gender. According to this we argue that there will be more Croatian CLI in the area of morphology.

\section{METHOD}

\subsection{Participants}

Our total sample is composed of 30 participants, 16 females and 14 males and they can be grouped between the ages of 21-29. All the participants had exclusively Croatian as a first languge, English as a second language, and were learning Spanish as a third language at the time of the study.They were all enrolled in Intermediate Spanish course at Rochester Institute of Technology. Students enroll Intermediate Spanish in their junior year after successfully passing two semesters of Beginning Spanish (total of 120 hours). They all stated that they had never been to a Spanish speaking country and that their first contact with Spanish language was when they enrolled Beginning Spanish course. All of them are higly proficient in English language since they started learning English in their early childhood and since their lessons at RIT are all held in English language.

\subsection{Instrument}

We used a corpus made of compositions written during the final exam. According to Bayona (2009) students' production in free composition is thought to reflect more accurately their grammatical and communicative competence. The students were already 
familiar with this kind of a task as it was an obligatory part of the final exam at the end of each semester even in the prior years of the study of the foreign language. Apart from establishing a topic, the instructor had no other intervention. The topic was related to the material presented in class.

\subsection{Procedures}

Demographic and linguistic background data were collected by means of a language profile questionnaire, which was completed by students after the exam. The design of the questionnaire was based on an adaptation of an earlier version of the linguistic profile "Language experience and Proficiency Questionnaire (LEAP-Q)" designed and employed by Marian et al. (2006). The students were told that the terms first, second and third language referred to the order of acquisition of each language respectively.

Data were collected from free compositions written during the regular final exam and the participants were the students enrolled in Intermediate Spanish course at Rochester Institute of Technology, all native speakers of Croatian with L2 English. None of the participants were allowed to use a dictionary and they were required to write approximately 200 words within the 100 minutes allocated for the entire test. We didn't exclude any individual because they all met the criteria for the selection due to their linguistic background. First we extracted the errors and classified them according to the possible influence from Croatian or English language that might have caused them. In addition we did an error analysis database with the lexical, morphological and syntactic features that these errors exhibited in order to corroborate our hypotheses that formal similarity in different areas of language can be the important trigger for language transfer. In addition we did an error analysis for each participant separately in order to corroborate the first hypothesis which claims that the production of CLI is a tangible representation of the simultaneous activation of all three languages which is also in accordance with the term combined CLI (De Angelis, 2007).

Our study is focused on those errors that are clearly traceable to previously acquired languages, leaving aside those errors that are independent of CLI. These transfer errors are divided into four categories: transfer error in syntax, lexicon and morphology . Following is the description of the error categories used to classify the CLI detected in our corpus. As mentioned before, since we are interested mainly in errors that reflect a CLI either at the lexical, morphological or syntactic level, we categorize them according to whether the influence can be assumed to come from Croatian, from English, or from both languages -"Ambiguous Items" (Bayona, 2009), in the case where we could not determine the exact origin of the CLI but we saw influence from both languages. ( e.g. the verb to love in Croatian is translated as voljeti and it is used in the same way as in English to express two things - to love a person or to love to do something. But in Spanish the verb querer means just to love a person, where for to love to do something the verb gustar is used. In this case and in other similar cases we can not be sure about the exact origin of CLI, because Croatian and English use the same form). 


\section{Lexicon}

Six subcategories of errors are included here:

a) Errors caused by a single Croatian/English item which corresponds to different Spanish items

$\begin{array}{ll}\text { Target form } & \text { He atendido a una presentación } \\ \text { Croatian } & \text { He asistido a una presentación } \\ \text { English } & \text { Sudjelovao sam na prezentaciji } \\ & \text { I attended a presentation }\end{array}$

b) Words with same meaning but different grammatical features

$\begin{array}{ll} & \text { Toda la gente estaban alegres } \\ \text { Target form: } & \text { Toda la gente estaba alegre } \\ \text { Croatian: } & \text { Svi ljudi su bili sretni } \\ \text { English: } & \text { All the people were happy }\end{array}$

c) False cognates

Another type of lexical transfer error is caused by the erroneous use of the so-called "false" cognates. Learners assume that words which are similar in form are also similar in meaning.

$\begin{array}{ll} & \text { Estudiaba en la librería } \\ \text { Target form: } & \text { Estudiaba en la biblioteca } \\ \text { Croatian: } & \text { Učio sam u knjižnici } \\ \text { English: } & \text { I used to study in the library } \\ \text { d) Loan Translations (or calques) } \\ \text { These errors are the result of a direct word-for-word translation of an Croatian/ } \\ \text { sh phrase or idiom. }\end{array}$

Tuvimos un buen tiempo

Target form: $\quad$ Nos lo pasamos muy bien

Croatian: Dobro smo se proveli

English: We had a good time

e) Borrowing - also called "code switching" (see. e.g. James, 1998) appears when the learner directly inserts an L1/L2 words into the L3 syntax.

Target form: $\quad$ Estoy muy agradecida

Croatian: Vrlo sam zahvalna

English: I'm very grateful 
f) Coinage or "relexification" (see, e.g. Ringbom, 1983) consists of the adaption of an L1 word to the L2 orthography or morphology. For this study purpose we tried to find adaptations of an L1/L2 word to the L3 orthography or morphology.

$\begin{array}{ll}\text { Target form: } & \text { Mi familia es muy comprensiva } \\ \text { Croatian: } & \text { Moja obitelj je puna razumijevanja } \\ \text { English: } & \text { My family is very supportive }\end{array}$

\section{Syntax}

Syntactical errors attributed to L1/L2 interference appear when the student tries to equate parts of Spanih and Croatian/English construtcion. We have classified syntactical transfer errors within three subcategories: a) errors in word order, b) errors of omission and $\mathrm{c}$ ) errors of addition

a) Word order

The students tend to invert the order of noun and modifier by following the word order of the Croatian / English parallel construction.
Target form:
El menor hermano
Croatian:
El hermano menor
English:
Mlađi brat
The younger brother

b) Omission

This type of syntactical transfer error is caused by the student's tendency to omit a required grammatical element in Spanish which is optional, or non-existing, in the Croatian/English parallel construction.

$\begin{array}{ll} & \text { Me gustaba visitar mis abuelos } \\ \text { Target form: } & \text { Me gustaba visitar a mis abuelos } \\ \text { Croatian: } & \text { Voljela sam posjećivati moju baku i djeda } \\ \text { English: } & \text { I loved visiting my grandparents }\end{array}$

c) Addition

Sometimes Croatian/English constructions cause interference in corresponding Spanish patterns because the student transposes a compulsory Croatian/English element literally into the Spanish construction where that element has no correspondence.

$\begin{array}{ll} & \text { Esperaba para mi madre } \\ \text { Target form: } & \text { Esperaba a mi madre } \\ \text { Croatian: } & \text { Čekala sam majku } \\ \text { English: } & \text { I was waiting for my mother }\end{array}$




\section{Morphology}

In data collected for this study, morphological errors attributed to transfer were classified into

a) errors of gender and number marking and b) errors of subject-verb agreement

a) Spanish nouns, articles and adjectives agree in gender and number the same as in Croatian language whereas English articles and adjectives are invariable for gender and number except for this and that.

b) English doesn't present verb inflection and agreement but the Croatian language does.

Mi Navidad favorito (target form: Mi Navidad favorita)- Croatian: Moj omiljeni Božić

\section{RESULTS AND DISCUSSION}

These compositions provided us with an extensive corpus from which we could extract 434 tokens through error analysis of which 195 were lexical items with crosslinguistic influence. As can been seen in Table 1, L1 (Croatian language) influence is the cause behind $31 \%$ of all of these errors, L2 (English language) influence is the cause behind $43 \%$ of all the errors and we have $26 \%$ Ambigous Items.

Table 1 : Type of CLI according to origin

\begin{tabular}{|l|ll|}
\hline $\begin{array}{l}\text { Type of CLI according } \\
\text { to origin }\end{array}$ & Frequency (\%) \\
\hline CRO CLI & 61 & $(31 \%)$ \\
\hline ENG CLI & 84 & $(43 \%)$ \\
\hline Ambiguous Items & 50 & $(26 \%)$ \\
\hline Total & 195 & $(100 \%)$ \\
\hline
\end{tabular}

These 195 errors were categorized by type of error into three main groups: The results (Table 2) show that $64 \%$ of all interference errors were committed in the area of lexicon, out of which 66\% with ENG CL (Table 4) 7\% with CRO CLI (Table 3) and 27\% are Ambiguous Items (Table 5); $11 \%$ in syntax (Table 2), out of which $10 \%$ with ENG CLI (Table 4), 14\% with CRO CLI (Table 3) and $76 \%$ are Ambiguous Items (Table 5) and $25 \%$ of all transfer errors were found in morphology and all of them with CRO CLI (Table $3)$. The most common errors in order of frequency were those caused by word-for-word translation ( $26 \%$ of all transfer errors), errors caused by adaptations of an L1/L2 word to the L3 orthography or morphology ( $20 \%$ of all transfer errors ), errors caused by a single Croatian/English item corresponding to different Spanish items (10\% of all transfer errors), and errors caused by omission of a required Spanish element when that element has no counterpart in the Croatian/English equivalent expression ( $8 \%$ of all transfer errors).

The strongest English language influence is found in the area of lexicon $(66 \% \mathrm{ENG}$ CLI) keeping in mind that $27 \%$ of these errors are Ambiguous Items, ( the case where we 
could not determine the exact origin of the CLI but we saw influence from both languages) which confirms our statement that the formal similarity between specific components of language (here lexical similariity between Spanish and English) plays a key role in a language transfer. The most common errors with ENG CLI in order of frequency within the area of lexicon were those caused errors caused by adaptations of an L2 (English) word to the L3 (Spanish) orthography or morphology (48\% of the errors within this subcategory) followed by word-for-word translations ( $25 \%$ of the errors within this subcategory). We found only 7 examples of direct borrowing. Although this wasn't the primary purpose of our research, these results show and confirm the findings of preceding research by Ringbom $(2001,2006)$. He states that errors of creativity, for example coinages, or calques are evidence that the learner is growing up in the use of language and that as learners grow older and go up grade, the presence of borrowings in their compositions becomes rarer.

As mentioned before basic syntax is typologically similar to a great extent in these three languages so we didn't expect to find major errors in syntax and the results confirmed our hypotheses. We had only $11 \%$ syntactic errors. In the area of syntax the most common errors were those caused by omission of a required Spanish element, and $76 \%$ of the errors within this subcategory were Ambigous Items.

The strongest L1 (Croatian) influence is found in the area of morphology $(100 \%$ CRO CLI) and all the errors were found in the area of gender and number marking which also confirms our hypotheses that in the area of morphology students will rely more on Croatian language in language transfer due to morphologycal similarity between these two languages. In this research students didn't have trouble with Spanish verb morphology related to person and number due to the fact that Croatian language presents verb inflection and agreement.

Table 2: Type of CLI according to typology of error

\begin{tabular}{|l|l|lc|}
\hline CLI according to typology of error & Subcategories of errors & Frequency \\
\hline Lexical Errors & $\begin{array}{l}\text { Errors caused by a single Croatian/En- } \\
\text { glish item which corresponds to different } \\
\text { Spanish items }\end{array}$ & $20 \quad(10 \%)$ \\
& $\begin{array}{l}\text { Words with same meaning but different } \\
\text { grammatical features }\end{array}$ & $2 \quad(1 \%)$ \\
\hline & False cognates & 5 & $(3 \%)$ \\
\hline & Calques & $51 \quad(26 \%)$ \\
\hline & Code switching & 7 & $(4 \%)$ \\
\hline & Coinage & $40 \quad(20 \%)$ \\
\hline Total-Lexical erors & & $\mathbf{1 2 5}(\mathbf{6 4 \%})$ \\
\hline Syntactic errors & Word order & 3 & $(2 \%)$ \\
\hline & Omission & $16 \quad(8 \%)$ \\
\hline & Addition & 2 & $(1 \%)$ \\
\hline Total-syntactic errors & & $\mathbf{2 1} \quad(\mathbf{1 1 \%})$ \\
\hline Morphological errors & Gender and number marking & $49 \quad(25 \%)$ \\
\hline Total-morphological errors & & $49 \quad(25 \%)$ \\
\hline Total & & $195 \quad(100 \%)$ \\
\hline
\end{tabular}


Table 3: Type of CRO CLI according to typology of error

\begin{tabular}{|l|l|lc|}
\hline CRO CLI according to typology of error & Subcategories of errors & Frequency \\
\hline Lexical errors & $\begin{array}{l}\text { Errors caused by a single Croatian } \\
\text { item which corresponds to different } \\
\text { Spanish items }\end{array}$ & $1 \quad(2 \%)$ \\
\hline & $\begin{array}{l}\text { Words with same meaning but differ- } \\
\text { ent grammatical features }\end{array}$ & 0 & $(0 \%)$ \\
\hline & False cognates & 0 & $(0 \%)$ \\
\hline & Calques & 8 & $(13 \%)$ \\
\hline & Code switching & 0 & $(0 \%)$ \\
\hline Total-Lexical errors & Coinage & 0 & $(0 \%)$ \\
\hline Syntactic errors & & $\mathbf{9}$ & $\mathbf{( 7 \% )}$ \\
\hline & Word order & 0 & $(0 \%)$ \\
\hline & Omission & $3 \quad(5 \%)$ \\
\hline Total-Syntactic errors & Addition & $0 \quad(0 \%)$ \\
\hline Morphological errors & & $\mathbf{3} \quad(\mathbf{1 4 \% )}$ \\
\hline Total-morpgological errors & Gender and number marking & $49(80 \%)$ \\
\hline Total & & $49 \quad(100 \%)$ \\
\hline
\end{tabular}

Table 4: Type of ENG CLI according to typology of error

\begin{tabular}{|l|l|lc|}
\hline ENG CLI according to typology of error & Subcategories of errors & Frequency \\
\hline Lexical errors & $\begin{array}{l}\text { Errors caused by a single English } \\
\text { item which corresponds to different } \\
\text { Spanish items }\end{array}$ & 9 & $(11 \%)$ \\
\hline & $\begin{array}{l}\text { Words with same meaning but } \\
\text { different grammatical features }\end{array}$ & 0 & $(0 \%)$ \\
\hline & False cognates & 5 & $(6 \%)$ \\
\hline & Calques & 21 & $(25 \%)$ \\
\hline & Code switching & 7 & $(8 \%)$ \\
\hline Total-Lexical errors & Coinage & 40 & $(48 \%)$ \\
\hline Syntactic errors & & $\mathbf{8 2}$ & $\mathbf{( 6 6 \% )}$ \\
\hline & Word order & 0 & $(0 \%)$ \\
\hline & Omission & 0 & $(0 \%)$ \\
\hline Total-Syntactic errors & Addition & 2 & $(2 \%)$ \\
\hline Morphological errors & & $\mathbf{2}$ & $\mathbf{( 1 0 \% )}$ \\
\hline Total-morphological errors & Gender and number marking & 0 & $(0 \%)$ \\
\hline Total & & 0 & $(0 \%)$ \\
\hline
\end{tabular}


Table 5 : Type of ENG/CRO CLI according to typology of error

\begin{tabular}{|l|l|lc|}
\hline $\begin{array}{l}\text { ENG/CRO CLI according to typology } \\
\text { of error }\end{array}$ & Subcategories of errors & Frequency \\
\hline Lexical errors & $\begin{array}{l}\text { Errors caused by a single Croatian/ } \\
\text { English item which corresponds to } \\
\text { different Spanish items }\end{array}$ & 10 & $(20 \%)$ \\
\hline & $\begin{array}{l}\text { Words with same meaning but different } \\
\text { grammatical features }\end{array}$ & 2 & $(4 \%)$ \\
\hline & False cognates & 0 & $(0 \%)$ \\
\hline & Calques & 22 & $(44 \%)$ \\
\hline & Code switching & 0 & $(0 \%)$ \\
\hline & Coinage & 0 & $(0 \%)$ \\
\hline Total-Lexical errors & & $\mathbf{3 4}$ & $\mathbf{( 2 7 \% )}$ \\
\hline Syntactic errors & Word order & 3 & $(6 \%)$ \\
\hline & Omission & 13 & $(26 \%)$ \\
\hline & Addition & 0 & $(0 \%)$ \\
\hline Total-Syntactic errors & & $\mathbf{1 6}$ & $\mathbf{( 7 6 \% )}$ \\
\hline Morphological errors & Gender and number marking & 0 & $(0 \%)$ \\
\hline Total-Morphological errors & & 0 & $(0 \%)$ \\
\hline Total & & 50 & $(100 \%)$ \\
\hline
\end{tabular}

Table 6: Type of CLI according to origin per subject

\begin{tabular}{|c|c|c|c|}
\hline Participant number & Errors with CRO CLI & Errors with ENG CLI & Errors with ENG/CRO CLI \\
\hline 1 & 2 & 6 & 2 \\
\hline 2 & 2 & 4 & 1 \\
\hline 3 & 3 & 1 & 2 \\
\hline 4 & 2 & 2 & 1 \\
\hline 5 & 3 & 1 & 3 \\
\hline 6 & 1 & 4 & 1 \\
\hline 7 & 2 & 2 & 2 \\
\hline 8 & 1 & 4 & 3 \\
\hline 9 & 1 & 2 & 2 \\
\hline 10 & 4 & 4 & 1 \\
\hline 11 & 2 & 2 & 1 \\
\hline 12 & 3 & 1 & 2 \\
\hline 13 & 2 & 5 & 1 \\
\hline 14 & 1 & 5 & 1 \\
\hline 15 & 2 & 1 & 3 \\
\hline 16 & 2 & 1 & 1 \\
\hline 17 & 2 & 3 & 1 \\
\hline 18 & 1 & 6 & 2 \\
\hline 19 & 3 & 3 & 2 \\
\hline 20 & 1 & 2 & 3 \\
\hline 21 & 3 & 1 & 0 \\
\hline 22 & 1 & 1 & 1 \\
\hline 23 & 2 & 2 & 2 \\
\hline 24 & 1 & 6 & 1 \\
\hline 25 & 2 & 1 & 2 \\
\hline 26 & 3 & 1 & 3 \\
\hline 27 & 3 & 4 & 2 \\
\hline 28 & 2 & 2 & 0 \\
\hline 29 & 4 & 2 & 2 \\
\hline 30 & 1 & 5 & 2 \\
\hline
\end{tabular}


As can been seen in Table 6 none of the participants was influenced exclusively by L1 or L2. These results show and confirm our hypotheses that the transfer can occur from more than one language at the same time.

Due to the fact that we have $31 \%$ CRO CLI, $43 \%$ ENG CLI and 26\% Ambiguous Items within the total CLI and that all the participants were influenced by all three languages it can be stated that the production of CLI in our study may be taken as evidence that our third language learners were in a concurrent state of activation- as opposed to the gradual activation proposed by Grosjean (2001)-at the time of writing their composition. In other words we provide quantitative evidence that all three languages were active in the language mode of the subject during the process of writing the composition in Spanish, and that this activation was independent of external faxtors since our participants were not aware that their writing would be evaluated for research purposes. Therefore we argue that the language mode in third language learners shows a simultaneous activation of all three languages that make up their language mode, which allows the production of CLI from all previously acquired languages when performing in the L3, as it has been evidenced in the compositions of our participants. This is also in accordance with De Angelis (2007) statement that transfer occurs from more than one language at the same time. Furthermore, our findings allow us to support De Angelis' (2007) statement that formal similarity between specific features or components of languages plays the key role in language transfer as in our case was the lexical similarity between English and Spanish and morphologycal similarity between Croatian and Spanish.

\section{CONCLUSION}

The present study has examined the production of CLI in trilingual learners who have Croatian as a first language and English as a second language, and who are in in the process of acquiring Spanish as a third language. The results of the research confirmed our initial hypotheses that the production of CLI is a tangible representation of the simultaneous activation of all the languages present in the individual's Language Mode (Grosjean, 2001) or in other words that the transfer occurs from more than one language at the same time (De Angelis,2007) and that the type of transfer episodes observed may be related to formal similarity between specific features or components of language.

Other variables that appear to play a key role in L3 acquisition as Hammarberg (2001) states are the level of proficiency and recency. In this study the proficiency and recency factors were neutralized due to the fact that all our participants were higly proficient in L2 and had formal instruction in L2. Maybe future studies that explore other variables affecting multilingual transfer under same language pairings would tell us more about the dynamic nature of linguistic transfer itself.

\section{References:}

Bayona, P. (2009). Crosslinguistic influences in the acquisition of Spanish L3: UMI Dissertations Publishing. 
Bardel, C. and Falk, Y. (2007). The role of the second language in third language acquisition: The case of Germanic syntax. Second Language Research, 23: 459-484.

Bouvy, C. (2000). Towards the Construction of a Theory of Cross-linguistic Transfert. In Cenoz, J., and Jessner, U (Eds.) (2000) English in Europe. The Acquisition of a Third language. Clevedon: Multilingual Matters: 143-156.

Cenoz, J., Hufeisen, B., and Jessner, U (Eds.) (2001), Cross-linguistic Influence in Third language Acquisition: Psycholinguistic Perspectives: Clevedon, UK: Multilingual Matters.

Cenoz, J. (2003). The role of typology in the organization of the multilingual lexicon. In Cenoz, J., Hufeisen, B., and Jessner, U (Eds.) (2003) The multilingual lexicon. Dordrecht, the Netherlands: Kluwer: 103-116.

Corder, S. (1967). The significance of learners' errors. International Review of Applied Linguistics, 5: 161-170.

De Angelis, G. (2007). Third or additional language acquisition. Clevedon, UK: Multilingual Matters.

Flynn, S., Foley, C., and Vinnitskaya, I. (2004). The cumulative-enhancement model for language acquisition: Comparing adults' and children's patterns of development in first, second and third language acquisition. International Journal of Multilingualism, 1: 3-17.

Grosjean, F. (2001). The Bilingual's Language Modes. In J. Nicol (Ed.), One Mind, Two languages: Bilingual Language Processing. Malden, MA: Blackwell Publishers: 1-22.

Grosjean, F. (2004). Issue in Studying Bilinguals. In Bhatia, T., and Ritchie, W (Eds.) (2004) The Handbook of Bilingualism. Malden, MA: Oxford.

Hammarberg, B. (2001). Roles of L1 and L2 in L3 Production and Acquisition. In Cenoz, J., Hufeisen, B., and Jessner, U (Eds) (2001) Cross-linguistic Influence in Third Language Acquisition: Psycholinguistic Perspectives. Clevedon: Multilingual Matters: 21-41.

James, C. (1998). Errors in Language Learning and Use: Exploring Error Analysis. London: Longman.

Lado, R. (1957). Linguistic Across Cultures. Ann Arbor: Univerity of Michigan Press.

Leung, Y.-K. I. (2005). L2 vs. L3 initial state: A comparative study of the acquisition of French DPs by Vietnamese monolinguals and Cantonese-English bilinguals. Bilingualism: Language and Cognition, 8(1): 39-61.

Marian, V., Blumenfeld, H., and Kaushanskaya, M. (2006). The Language Experience and Proficiency Questionnaire (OLEAP-Q): Assessing Language Profiles in Bilinguals and Multilinguals. Toronto: Conference on Second Language Acquisition and Multilingualism. York University.

Ringbom, H. (1983). Borrowing and lexical transfer. Applied Linguistics, 4: 207- 212.

Rothman, J., and Cabrelli Amaro, J. (2010). What variables condition syntactic transfer? A look at the L3 initial state. Second Language Research, 26: 189-218.

Sharwood Smith, M. and Kellerman, E. (1986). Crosslinguistic Influence in Second Language Acquisition : An introduction. In Kellerman, E., and Sharwood Smith, M (Eds.) Crosslinguistic Influence in Second Language Acquisition. New York: Pergamon Press.

Williams, S and Hammarberg, B. (2009). Language switches in L3 production: Implications for a polyglot speaking model. In Hammarberg, B (Ed.) (2009) Processes in third language acquisition, 28.73. Edinburgh University Press. Originally 1998 in Applied Linguistics 19(3): 295-333. 
Appendix

LINGUISTIC PROFILE ${ }^{1}$

\begin{tabular}{|l|l|l|}
\hline Last name & First name & Gender \\
\hline Age & & \\
\hline
\end{tabular}

Please select the appropriate responese from the choices given:

1.Croatian is my

a) First language

b) Second language

c) Third language

d) Fourth language

2.English is my

a) First language

b) Second language

c) Third language

d) Fourth language

3.Spanish is my

a) First language

b) Second language

c) Third language

d) Fourth language

Regarding your knowledge of English:

4. Age when you:

\begin{tabular}{|l|l|l|l|}
\hline Began acquiring it & Became fluent & Began reading it & Became fluent reading it \\
\hline
\end{tabular}

5. Please state the number of years and months you spent in:

\begin{tabular}{|l|l|l|}
\hline & Years & Months \\
\hline A country where English is spoken & & \\
\hline A family where English is spoken & & \\
\hline A school where English is spoken & & \\
\hline
\end{tabular}

1 Adapted from: Marian, V., H. Blumenfeld. and M. Kaushanskaya. (2006). The Language Experience and Proficiency Questionnaire (OLEAP-Q): Assessing Language Profiles in Bilinguals and Multilinguals. Toronto: Conference on Second Language Acquisition and Multilingualism. York University 


\section{Barbara Perić}

Nikolina Božinović

Sažetak: Ovo istraživanje proučava ulogu prethodno stečenih jezika u procesu usvajanja trećeg jezika . U centru pažnje ovog istraživanja su međujezični uticaji prilikom usvajanja španskog jezika kao trećega stranog jezika, na učenike kojima je hrvatski jezik prvi/ materinji jezik, a engleski drugi jezik. Kako De Angelis (2007) navodi, utvrđeno je da je jezični prenos moguć iz više od jednog jezika u isto vreme. Ova vrsta prenosa koji se naziva kombinovani međujezični uticaji (Combined CLI) je malo istražena do danas. Kroz analizu grešaka ovo istraživanje pokazuje da je postojanje međujezičnih uticaja opipljiv dokaz istovremenog aktiviranja svih jezika Language Modea svakoga pojedinca (Grosjean, 2001). Istraživanje takođe potvrđuje da vrsta promatranog jezičnog prenosa može biti povezana sa formalnom sličnosti između određenih funkcija ili komponenti jezika.

Ključne riječi: Usvajanje trećeg jezika, Međujezični uticaji, Language Mode, Prenos, Analiza grešaka, Formalna sličnost 